Фармацевтичний менеджмент, маркетинг та логістика

Pharmaceutical management, marketing and logistics

Рекомендована д. фрармац. наук, проф. В. В. Трохимчуком

УДК 615.036:615.216.84:617.7-007.681

DOI 10.11603/2312-0967.2016.3.6824

\title{
ЕКСПЕРТНА ОЦІНКА ЛІКАРСЬКИХ ЗАСОБІВ ГРУПИ SО1Е «ПРОТИГЛАУКОМНІ ПРЕПАРАТИ ТА МІОТИКИ»
}

\section{(C) О. В. Кривов'яз}

\author{
Вінницький національний медичний університет імені М. І. Пирогова
}

\begin{abstract}
Резюме: проведено анкетування 280 лікарів-спеціалістів (офтальмологів та лікарів загальної практики - сімейної медицини) з метою експертної оцінки препаратів групи S01E «Протиглаукомні препарати та міотики». Розраховано сумарні та середні оцінкові характеристики кожного з досліджуваних препаратів за показниками есективності, наявності побічної дії, фрактичної вірогідності призначення препарату на сьогодні, перспективності застосування препарату, наявності в аптечній мережі. Згідно з отриманими даними здійснено ранжування протиглаукомних препаратів на групи високої, середньої та низької доцільності включення у фрормулярні та страхові переліки.
\end{abstract}

Ключові слова: первинна відкритокутова глаукома, протиглаукомні препарати, експертна оцінка, формулярний та страховий переліки.

Вступ. В умовах постійного зростання потреб населення в наданні якісної медичної та фрармацевтичної допомоги есрективним важелем між витратами на забезпечення хворих лікарськими засобами (ЛЗ) та обмеженими ресурсами охорони здоров'я $€$ фрормування орормулярної системи (ФС) [1, 2]. Особливої актуальності використання ФС в галузі охорони здоров'я набуває у випадках лікування хронічних хворих, до яких, зокрема, належать пацієнти з первиною відкритокутовою глаукомою (ПВКГ) [3, 4]. Також впровадження ФС в практику лікаря та провізора дозволяє оптимізувати процес закупівлі та приймання протиглаукомних препаратів (ПГП) при лікуванні пацієнтів [5].

у дослідженнях організаційно-економічного напрямку у фармації та медицині метод експертної оцінки Л3 має широке використання [6]. За його допомогою визначають фрактичне ставлення спеціалістів відповідної галузі медицини до питань ефективності та застосування препаратів при лікуванні тих чи інших патологій. При обробці переліку призначених лз беруть до уваги думки найбільш кваліфрікованих спеціалістів зі значним досвідом роботи. На основі даних експертів розробляють шляхи оптимізації фармацевтичного забезпечення хворих, у тому числі формування фрормулярів [7].

Тому метою нашої роботи була розробка організаційно-економічних заходів щодо рекомендацій до включення у фрормулярний перелік (ФП) ЛЗ групи S01E «Протиглаукомні препарати та міотики», які застосовуютья при лікуванні хворих на ПВКГ, шляхом експертної оцінки.

Методи дослідження. Нами було проведено анкетування 280 лікарів-спеціалістів (офртальмологів та лікарів загальної практики - сімейної медицини)
Вінницької та Дніпропетровської областей України, теоретичні знання та практичний досвід яких дозволили провести всебічний аналіз асортименту препаратів, що використовуютья при лікуванні хворих на ПВКГ, а також дати оцінку нинішньої ситуації за ступенем задоволеності цими лікарськими препаратами і вказати фрактори, які фрормують споживання та потребу протиглаукомних лікарських засобів в Україні. Таким чином було розроблено анкету «Експертна оцінка препаратів, які застосовуються при лікуванні хворих на первинну відкритокутову глаукому», складену за стандартними вимогами (рис. 1).

Перший розділ анкети - «загальні відомості» включав «паспортну» частину, у якій експерти вказували дату заповнення анкети, місце (район та область) знаходження та назву установи, в якій працюють, зазначали лікарську спеціальність і посаду. Інорормація, за якою в подальшому було розраховано рівень компетентності експерта, аналізувалась за показниками: стаж роботи за спеціальністю, наявність кваліфрікаційної категорії (друга, перша, вища) та вченого ступеня і звання, самооцінка за 5-бальною шкалою (від 1 - «слабкі» до 5 - «найкращі») за показниками теоретичних знань в області лікування глаукоми, а також практичних навичок та досвіду у вищевказаній області. Стаж роботи інтерпретували за трибальною шкалою: до 10 років включно - 1 бал, від 11 до 20 років - 2 бали, понад 20 років - 3 бали. Наявність кваліфікаційної категорії: друга - 1 бал, перша - 2 бали, вища - 3 бали. Вчений ступінь і звання: кандидат наук / доцент - 1 бал, доктор наук / професор - 2 бали. Таким чином, максимально можлива компетентність експерта за наведеною анкетою могла

ISSN 2312-0967. Фармацевтичний часопис. 2016. № 3 
Фармацевтичний менеджмент, маркетинг та логістика Pharmaceutical management, marketing and logistics

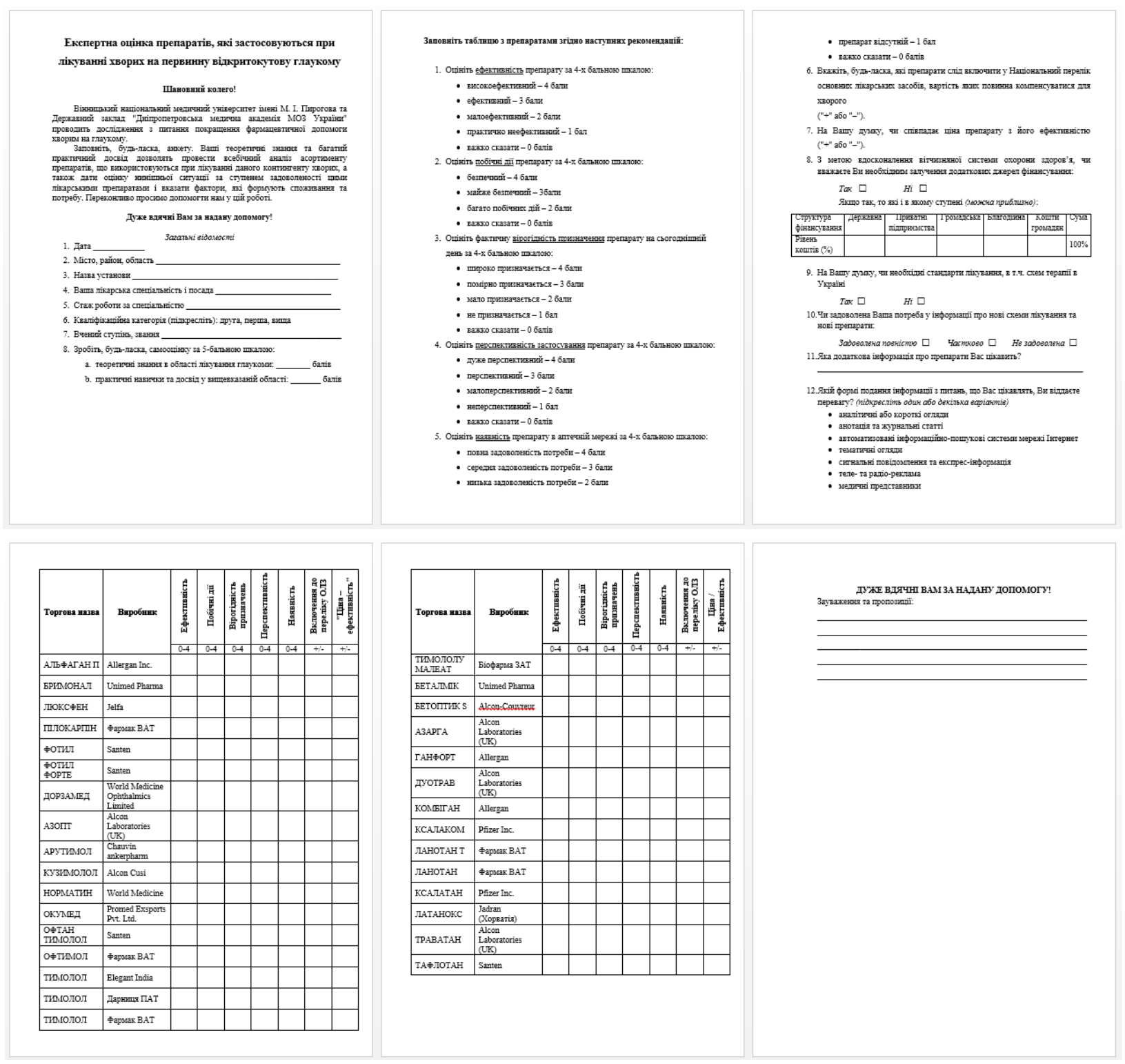

Рис. 1. Анкета-опитувальник для лікарів з експертної оцінки препаратів, які застосовують при лікуванні хворих на первинну відкритокутову глаукому.

становити 18 балів. Рівень компетентності експерта $\left(\mathrm{L}_{\mathrm{EC}}\right)$ було розраховано за фрормулою (1):

$$
L_{E C}=\frac{E_{w}+C_{q}+D_{a}+S_{p}+K_{t}}{18},(1)
$$

де $\mathrm{L}_{\mathrm{EC}}$ - рівень компетентності експерта, од.;

$\mathrm{E}_{w}$ - стаж роботи за спеціальністю, балів;

$\mathrm{C}_{\mathrm{q}}$ - кваліфікаційна категорія, балів;

$\mathrm{D}_{\mathrm{q}}^{\mathrm{q}}$ - вчений ступінь і звання, балів;

$\mathrm{S}_{\mathrm{p}}^{\mathrm{a}}$ - рівень теоретичних знань в області лікування глаукоми, балів;

$\mathrm{K}_{\mathrm{t}}$ - рівень практичних навичок та досвіду в області лікування глаукоми, балів;

18 - максимально можливий рівень компетентності експерта, балів.
Другий розділ анкети - «експертна» частина - був призначений для оцінки запропонованих препаратів 3 групи S01E - «Протиглаукомні препарати та міотики», що зареєстровані на території України [8]. Експерти оцінювали еорективність, побічні дії, фрактичну вірогідність призначення препарату на сьогодні, перспективність застосування препарату, наявність препарату в аптечній мережі за шкалою від 4 (високоефективний, безпечний, широко призначається, дуже перспективний ЛП, потреба в якому повністю задоволена) до 0 (що означало, що відповідь на питання експерту дати важко). Крім того, експерти висловлювали свою думку щодо необхідності включення зазначених препаратів у Національний перелік основних лікарських засобів, та вартість яких повинна компенсуватися для хворо-

ISSN 2312-0967. Pharmaceutical review. 2016. № 3 
Фармацевтичний менеджмент, маркетинг та логістика Pharmaceutical management, marketing and logistics

го, а також відзначали відповідність критерію «вартість - едективність» для ПГП («+»-1 бал, «-»-0 балів). Поряд 3 цим, спеціалісти відзначали структуру фрінансування галузі охорони здоров'я в питанні лікування ПВКГ із зазначенням оптимального (на їхню думку) розподілу коштів з боку держави, приватних підприємств, громадських та благодійних організацій, власне пацієнтів.

На основі отриманих даних було розраховано сумарну характеристику кожного ПГП за всіма показниками, дану кожним з експертів, за фрормулою (2):

$$
C_{M M}=\sum_{i=1}^{m} C_{i},(2)
$$

де $C_{\text {мм }}$ - сумарна характеристика певного ПГП, дана одним експертом, балів;

$m$ - кількість показників, за якими оцінювали препарат $(\mathrm{n}=7)$;

$\mathrm{Ci}$ - характеристика певного ПГП за кожним із показників, балів.

Після цього було визначено середню оцінкову характеристику кожного ПгП за даними всіх експертів за фрормулою (3):

$$
\overline{E C_{M M}}=\frac{\sum_{i=1}^{n} L_{E C_{i}} * C_{M M}}{n},
$$

де $\overline{E C_{M M}}$ - середня оцінкова характеристика певного ПГП за даними всіх експертів, балів;

$n$ - кількість експертів, чол.;

$\mathrm{L}_{\mathrm{EC}}$ - рівень компетентності експерта, од.;

$C_{\text {мм }}$ - сумарна характеристика певного ПГП, дана одним експертом, балів.

Для розподілу препаратів на групи високої, середньої та низької доцільності включення до фрормулярних та страхових переліків визначали довжину кроку (s) за фрормулою (4):

$$
S=\frac{\overline{E C_{M M(\max )}}-\overline{E C_{M M(\min )}}}{3}
$$

де $\overline{E C_{M M(\max )}}$ - максимальне значення середньої оцінкової характеристики ПГП, балів;

$\overline{E C_{M M}(\min )}$ - найменше значення середньої оцінкової характеристики ПгП, балів;

3 - кількість груп ранжування, шт.

Результати й обговорення. Насамперед при аналізі анкет було визначено коефріцієнт компетентності кожного спеціаліста за фрормулою 1 на основі розрахунку показників використання номенклатури Л3, поінформованості спеціаліста, його кваліфрікаційного рівня, наукового авторитету (рис. 2).

Таким чином було встановлено, що проанкетовані лікарі-офтальмологи та лікарі загальної практики сімейної медицини мають коефіцієнт компетентності від 44,44 до 94,44\%. Рівень компетентності більшості експертів знаходився в межах 70 - $90 \%$, що відповідає високому рівню компетентності респондентів (рис. 2).

Другим етапом було розраховано сумарну бальну оцінку кожного з досліджуваних ПГП за даними експертної частини анкети. Після цього на основі отриманих результатів проводили порівняльну оцінку ЛП з наведеного в анкеті переліку, враховуючи значення середньої оцінкової характеристики кожного ПГП за даними всіх експертів (табл. 1).

Як видно з даних таблиці 1, максимальну оцінкову характеристику на рівні 13,03 балів експерти надали препаратам ОФТАН $®$ ТИМОЛОЛ Краплі очні 0,5 \% по 5 мл у срлаконі 3 крапельницею № 1 в картонній коробці виробник Сантен АТ, Фінляндія та АЗОПТ® Краплі очні, 10 мг/мл по 5 мл у фрлаконах-крапельни-

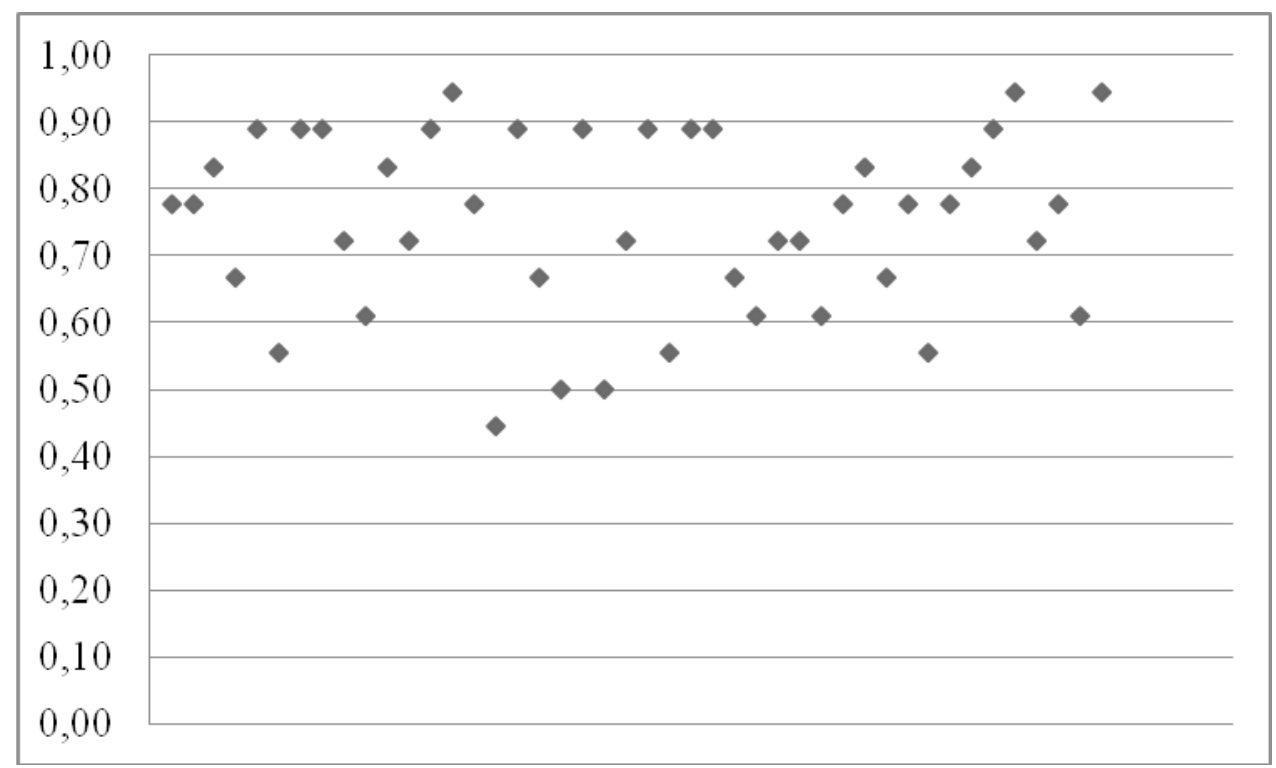

Рис. 2. Рівень компетентності експертів (\%) з оцінки протиглаукомних препаратів.

ISSN 2312-0967. Фармацевтичний часопис. 2016. № 3 
Фармацевтичний менеджмент, маркетинг та логістика Pharmaceutical management, marketing and logistics

Таблиця 1. Середня оцінкова характеристика протиглаукомних препаратів

\begin{tabular}{|c|c|c|c|}
\hline $\begin{array}{c}\text { Торгівельна назва } \\
\text { протиглаукомного } \\
\text { препарату }\end{array}$ & Виробник & $\begin{array}{l}\text { Кількість експертів, } \\
\text { що оцінили препарат }\end{array}$ & $\begin{array}{c}\text { Середня оцінкова } \\
\text { характеристика } \\
\text { препарату } \\
\end{array}$ \\
\hline Азарга & Алкон-Куврьор, Бельгія & 43 & 12,99 \\
\hline Азопт & Алкон-Куврьор, Бельгія & 44 & 13,03 \\
\hline Альфраган П & Аллерган Сейлс ЛЛС, США & 43 & 11,62 \\
\hline Арутимол & $\begin{array}{l}\text { Др. Герхард Манн, Хем.-фрарм. } \\
\text { Фабрик ГмбХ, Німеччина }\end{array}$ & 44 & 12,81 \\
\hline Беталмік & $\begin{array}{l}\text { ТОВ «УНІМЕД ФАРМА», } \\
\text { Словацька Республіка }\end{array}$ & 31 & 11,11 \\
\hline Бетоптик S & Алкон-Куврьор, Бельгія & 42 & 11,74 \\
\hline Бримонал & $\begin{array}{l}\text { ТОВ «УНІМЕД ФАРМА», } \\
\text { Словацька Республіка }\end{array}$ & 42 & 11,48 \\
\hline Ганфрорт & $\begin{array}{l}\text { Аллерган Фармасьютікалз } \\
\text { Ірландія, Ірландія }\end{array}$ & 40 & 11,78 \\
\hline Дорзамед & $\begin{array}{l}\text { К.О. «РОМФАРМ КОМПАНІ } \\
\text { С.Р.Л.», Румунія }\end{array}$ & 33 & 12,01 \\
\hline Дуотрав & Алкон-Куврьор, Бельгія & 39 & 12,13 \\
\hline Комбіган & $\begin{array}{l}\text { Аллерган Фармасьютікалз } \\
\text { Ірландія, Ірландія }\end{array}$ & 39 & 11,65 \\
\hline Ксалаком & $\begin{array}{l}\text { Пфрайзер Менюфекчуринг } \\
\text { Бельгія НВ, Бельгія }\end{array}$ & 35 & 11,77 \\
\hline Ксалатан & $\begin{array}{l}\text { Пфрайзер Менюсрекчуринг } \\
\text { Бельгія НВ, Бельгія }\end{array}$ & 37 & 12,16 \\
\hline Кузимолол & Алкон Кузі, С.А, Іспанія & 41 & 12,10 \\
\hline Ланотан & ПАТ «Фармак», Україна & 42 & 12,76 \\
\hline Ланотан Т & ПАТ «Фармак», Україна & 39 & 12,41 \\
\hline Латанокс & $\begin{array}{l}\text { «Ядран» Галенська Лабораторія } \\
\text { д.Д., Хорватія }\end{array}$ & 28 & 11,93 \\
\hline Люксфрен & ТОВ «Сантоніка», Литва & 27 & 11,63 \\
\hline Норматин & Е.І.П.І.Ко., Єгипет & 29 & 12,08 \\
\hline Окумед & Промед Експортс Пвт. Лтд., Індія & 34 & 11,66 \\
\hline Оортан тимолол & Сантен АТ, Фінляндія & 43 & 13,03 \\
\hline Офртимол & ПАТ «Фармак», Україна & 34 & 12,55 \\
\hline Пілокарпін & ПАТ «Фармак», Україна & 41 & 11,66 \\
\hline Тафрлотан & $\begin{array}{l}\text { Сантен АТ, Фінляндія } \\
\text { Сантен Фармасьютікал Ко, Лтд, } \\
\text { Сіга Плант, Японія }\end{array}$ & 42 & 12,83 \\
\hline Тимолол & Елегант Індія, Індія & 41 & 12,42 \\
\hline Тимолол-Дарниця & $\begin{array}{l}\text { ПрАТ «Фармацевтична фрірма } \\
\text { «Дарниця», Україна }\end{array}$ & 41 & 12,33 \\
\hline Тимолол & ПАТ «Фармак», Україна & 41 & 11,58 \\
\hline Тимолол-Біофрарма & $\begin{array}{l}\text { ВАТ «Біофрарма», м. Київ, } \\
\text { Україна }\end{array}$ & 36 & 12,27 \\
\hline Траватан & Алкон-Куврьор, Бельгія & 44 & 12,28 \\
\hline Фотил & Сантен АТ, Фінляндія & 40 & 12,25 \\
\hline Фотил фрорте & Сантен АТ, Фінляндія & 40 & 12,13 \\
\hline
\end{tabular}

цях «Дроп-Тейнер®» № 1 виробник Алкон-Куврьор, Бельгія. Мінімальну - 11,11 бала - отримав препарат БЕТАЛМІК 0,5 \% Краплі очні, розчин 0,5 \% по 5 мл або по 10 мл у фрлаконі-крапельниці № 1 виробник ТОВ
«УНІМЕД ФАРМА», Словацька Республіка. Таким чином довжина кроку s була встановлена за фрормулою 4 на рівні 0,64, що в подальшому було використано для ранжування ПГП на групи високої, середньої та

ISSN 2312-0967. Pharmaceutical review. 2016. № 3 
Фармацевтичний менеджмент, маркетинг та логістика Pharmaceutical management, marketing and logistics

низької доцільності включення до фрормулярних та страхових переліків (СП) (табл. 2).

Отже, до групи високої доцільності включення до фрормулярних переліків увійшло 9

Таблиця 2. Рівень доцільності включення протиглаукомних препаратів до фоормулярних та страхових переліків

\begin{tabular}{|c|c|c|c|c|}
\hline \multirow{2}{*}{$\begin{array}{c}\text { Торгівельна назва } \\
\text { протиглаукомного } \\
\text { препарату }\end{array}$} & \multirow{2}{*}{ Виробник } & \multicolumn{3}{|c|}{$\begin{array}{c}\text { Рівень доцільності включення до форомулярних та } \\
\text { страхових переліків }\end{array}$} \\
\hline & & високий & середній & низький \\
\hline Азарга & Алкон-Куврьор, Бельгія & & & \\
\hline Азопт & Алкон-Куврьор, Бельгія & & & \\
\hline Альфаган П & Аллерган Сейлс ЛЛС, США & & & \\
\hline Арутимол & $\begin{array}{l}\text { Др. Герхард Манн, Хем.-фрарм. } \\
\text { Фабрик ГмбХ, Німеччина }\end{array}$ & & & \\
\hline Беталмік & $\begin{array}{l}\text { ТОВ «УНІМЕД ФАРМА», } \\
\text { Словацька Республіка }\end{array}$ & & & \\
\hline Бетоптик S & Алкон-Куврьор, Бельгія & & & \\
\hline Бримонал & $\begin{array}{l}\text { ТОВ «УНІМЕД ФАРМА», } \\
\text { Словацька Республіка }\end{array}$ & & & \\
\hline Гансрорт & $\begin{array}{l}\text { Аллерган Фармасьютікалз } \\
\text { Ірландія, Ірландія }\end{array}$ & & & \\
\hline Дорзамед & $\begin{array}{l}\text { К.О. «РОМФАРМ КОМПАНІ } \\
\text { С.Р.Л.», РУмунія }\end{array}$ & & & \\
\hline Дуотрав & Алкон-Куврьор, Бельгія & & & \\
\hline Комбіган & $\begin{array}{l}\text { Аллерган Фармасьютікалз } \\
\text { Ірландія, Ірландія }\end{array}$ & & & \\
\hline Ксалаком & $\begin{array}{l}\text { Пфрайзер Менюоекчуринг } \\
\text { Бельгія НВ, Бельгія }\end{array}$ & & & \\
\hline Ксалатан & $\begin{array}{l}\text { Пфайзер Менюорекчуринг } \\
\text { Бельгія НВ, Бельгія }\end{array}$ & & & \\
\hline Кузимолол & Алкон Кузі, С.А, Іспанія & & & \\
\hline Ланотан & ПАТ «Фармак», Україна & & & \\
\hline Ланотан Т & ПАТ «Фармак», Україна & & & \\
\hline Латанокс & $\begin{array}{l}\text { «Ядран» Галенська } \\
\text { Лабораторія д.д., Хорватія }\end{array}$ & & & \\
\hline Люксфрен & ТОВ «Сантоніка», Литва & & & \\
\hline Норматин & Е.І.П.І.Ко., Єгипет & & & \\
\hline Окумед & $\begin{array}{l}\text { Промед Експортс Пвт. Лтд., } \\
\text { Індія }\end{array}$ & & & \\
\hline Офтан тимолол & Сантен АТ, Фінляндія & & & \\
\hline Офртимол & ПАТ «Фармак», Україна & & & \\
\hline Пілокарпін & ПАТ «Фармак», Україна & & & \\
\hline Тафрлотан & $\begin{array}{l}\text { Сантен АТ, Фінляндія } \\
\text { Сантен Фармасьютікал Ко, Лтд, } \\
\text { Сіга Плант, Японія }\end{array}$ & & & \\
\hline Тимолол & Елегант Індія, Індія & & & \\
\hline Тимолол-Дарниця & $\begin{array}{l}\text { ПрАТ «Фармацевтична фрірма } \\
\text { «Дарниця», Україна }\end{array}$ & & & \\
\hline Тимолол & ПАТ «Фармак», Україна & & & \\
\hline Тимолол-Біофарма & $\begin{array}{l}\text { ВАТ «Біофрарма», м. Київ, } \\
\text { Україна }\end{array}$ & & & \\
\hline Траватан & Алкон-Куврьор, Бельгія & & & \\
\hline Фотил & Сантен АТ, Фінляндія & & & \\
\hline Фотил фрорте & Сантен АТ, Фінляндія & & & \\
\hline
\end{tabular}

ISSN 2312-0967. Фармацевтичний часопис. 2016. № 3 
ПГП (АЗАРГА® Краплі очні по 5 мл у фрлаконах-крапельницях «Дроп-Тейнер®» № 1 виробник АлконКуврьор, Бельгія, АЗОПТ® Краплі очні, 10 мг/мл по 5 мл у фрлаконах-крапельницях «Дроп-Тейнер®» № 1 виробник Алкон-Куврьор, Бельгія, АРУТИМОЛ® Краплі очні, розчин 2,5 мг/мл по 5 мл у фрлаконікрапельниці, по 1 фрлакону-крапельниці у коробці виробник Др. Герхард Манн, Хем.-фрарм. Фабрик

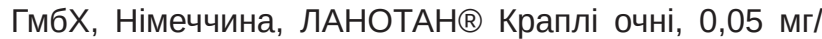
мл по 2,5 мл у фрлаконах 3 крапельницею № 1 ви-

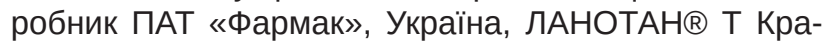
плі очні, розчин по 2,5 мл у фрлаконі № 1 виробник ПАТ «Фармак», Україна, ОФТАН® ТИмОЛОЛ Краплі очні 0,5 \% по 5 мл у фрлаконі 3 крапельницею № 1 в картонній коробці виробник Сантен АТ, Фінляндія, ОФТИМОЛ Краплі очні, 5 мг/мл по 5 мл або по 10 мл у орлаконі; по 1 фрлакону в пачці 3 картону виробник ПАТ «Фармак», Україна, ТАФЛОТАН® Краплі очні, 15 мгк/мл по 2,5 мл у фрлаконах № 1 виробник Сантен AT, Фінляндія, Сантен Фармасьютікал Ко, Лтд, Сіга Плант, Японія, ТИмОЛОЛ Краплі очні 0,5 \% по 5 мл у фрлаконах № 1 виробник Елегант Індія, Індія), що становить 29,03 \% від загальної кількості включених до анкети. Група середньої доцільності містила 13 препаратів (41,94\% номенклатури): ГАНФОРТ® Краплі очні по 3,0 мл у фрлаконі-крапельниці № 1 виробник Аллерган Фармасьютікалз Ірландія, Ірландія, ДОРЗАМЕД Краплі очні, розчин 2 \% по 5 мл у фрлаконі-крапельниці виробник К.О. «РОМФАРМ КОМПАНІ С.Р.Л.», Румунія, ДУОТРАВ® Краплі очні, по 2,5 мл, у фрлаконі-крапельниці № 1 виробник Алкон-Куврьор, Бельгія, КСАЛАКОМ Краплі очні, розчин по 2,5 мл у фллаконах № 1 виробник Пфрайзер Менюфекчуринг Бельгія НВ, Бельгія, КСАЛАТАН® Краплі очні, розчин 0,005 \% по 2,5 мл у поліетиленовому фрлаконі № 1

\section{Список літератури}

1. Бліхар В. Є. Медико-соціальне обґрунтування удосконалення фрормулярної системи лікарських засобів в системі охорони здоров'я України : автореф. дис. на здобуття наук. ступеня д-ра мед наук : спец. 14.02.03 / В. Є. Бліхар. - Київ, 2016. - 44 с.

2. Про затвердження Галузевої програми стандартизації медичної допомоги на період до 2020 року : наказ МОЗ України № 597 від 19.09.2011. - [Електронний ресурс]. - Режим доступу до ресурсу: http://www.moz.gov.ua/ua/ portal/dn_20110916_597.html

3. Глаукома первинна відкритокутова. Адаптована клінічна настанова, заснована на доказах. [Електронний ресурс]. - Режим доступу до ресурсу: www.dec.gov.ua/mtd/dodatki/816/816dod4_2.doc.

4. Damji K. F. Shields' Textbook of Glaucoma / K. F. Damji, S. Freedman, S. E. Moroi - [6-th ed.]. - Lippincott Williams \& Wilkins, 2010. -656 p. в картонній коробці виробник Пфайзер Менюфекчуринг Бельгія НВ, Бельгія, КУзІМОЛОЛ® Краплі очні 0,5 \% по 5 мл у фрлаконі-крапельниці № 1 виробник Алкон Кузі, С.А, Іспанія, ЛАТАНОКС® Краплі очні 0,005 \% по 2,5 мл у фрлаконах-крапельницях № 1 виробник «Ядран» Галенська Лабораторія д.д., Хорватія, НОРМАТИН Краплі очні 0,5 \% по 5 мл у фрлаконах-крапельницях № 1 виробник Е.І.П.І.Ко., Єгипет, ТИМОЛОЛ-ДАРНИЦЯ Краплі очні, розчин, 2,5 мг/мл по 5 мл або по 10 мл у фрлаконах № 1 виробник ПрАТ «Фармацевтична фрірма «Дарниця», Україна, ТИМОЛОЛ-БІОФАРМА Краплі очні 0,25 \% по 5 мл або по 10 мл у фрлаконах № 1 виробник ВАТ «Біофрарма», м. Київ, Україна, ТРАВАТАН® Краплі очні, 40 мкг/мл по 2,5 мл у фрлаконах-крапельницях № 1 у коробці виробник Алкон-Куврьор, Бельгія, ФОТИЛ® Краплі очні по 5 мл у фрлаконі-крапельниці № 1виробник Сантен AT, Фінляндія, ФОТИЛ® ФОРТЕ Краплі очні по 5 мл у фрлаконі - крапельниці № 1 виробник Сантен АТ, Фінляндія. Інші 9 препаратів виявлили низький рівень доцільності включення до ФП та СП.

Проведений аналіз анкет лікарів-спеціалістів в галузі офтальмології свідчить, що визначним фрактором у здійсненні вибору протиглаукомних засобів для включення їх до ФП та СП є критерій ефективності та відсутності побічних ефектів, тоді як найменший вплив на прийняття рішення має ціна препарату.

Висновки. Розроблено організаційно-економічні заходи щодо рекомендацій включення ПГП до ФП та СП. Встановлено, що вибірка лЗ з високим і середнім рівнем доцільності внесення до вищезазначених преліків складається 322 торгівельних назв ПГП (70,97 \% від номенклатури, що аналізувалась), які мали оцінкову характеристику в межах від 11,77 до 13,33 бала.

5. Воробьев П. А. Клинико-экономический анализ в медицинской организации : практическое руководство для лиц, принимающих решения / П. А. Воробьев // Рациональная фрармакотерапия. - 2008. - №1 (10). C. 5-14.

6. Панфілова Г. Л. Організація фрармацевтичної допомоги населенню в умовах медичного страхування : монографрія / Г. Л. Панфрілова, А. С. Немченко, О. А. Немченко. - Харків, 2009. - 228с.

7. Немченко А. С. Методологія фрормування фрормулярів і страхових переліків лікарських засобів за умов реалізації принципів Національної лікарської (фрармацевтичної) політики / А. С. Немченко, Г. Л. Панорілова // Фармацевтичний журнал - 2008. - № 3. - С. 16-22.

8. Державний реєстр лікарських засобів України. [Електронний ресурс]. - Режим доступу до ресурсу: http://www.drlz.com.ual

ISSN 2312-0967. Pharmaceutical review. 2016. № 3 
Фармацевтичний менеджмент, маркетинг та логістика

Pharmaceutical management, marketing and logistics

\title{
ЭКСПЕРТНАЯ ОЦЕНКА ЛЕКАРСТВЕННЫХ СРЕДСТВ ГРУППЫ S01Е «ПРОТИВОГЛАУКОМНЫЕ ПРЕПАРАТЫ И МИОТИКИ»
}

\author{
Е. В. Кривовяз \\ Винницкий национальный медицинский университет имени Н. И. Пирогова
}

Резюме: проведено анкетирование 280 врачей-специалистов (офтальмологов и врачей общей практики семейной медицины) с целью экспертной оценки препаратов группы S01E «Противоглаукомные препараты и миотики». Были рассчитаны суммарные и средние оценочные характеристики каждого из исследуемых препаратов по показателям эфффективности, наличия побочного действия, фрактической вероятности назначения препарата на сегодняшний день, перспективности применения препарата, наличия в аптечной сети. Базируясь на полученных данных произведено ранжирование противоглаукомных препаратов на группы высокой, средней и низкой целесообразности включения в формулярные и страховые перечни.

Ключевые слова: первичная открытоугольная глаукома, противоглаукомные препараты, экспертная оценка, фрормулярный и страховой перечени.

\section{EXPERT EVALUATION OF MEDICINES FROM SO1E PHARMACEUTICAL GROUP «ANTIGLAUCOMA MEDICINES AND MIOTICS»}

\section{O. V. Kryvoviaz}

\section{Pyrohov Vinnytsia National Medical University}

Summary: we have conducted questionnaire survey of 280 medical specialists (ophthalmologists and general practitioners - family doctors) with the purpose to make expert evaluation of medicines from S01E pharmaceutical group "Antiglaucoma medicines and miotics". We calculated the overall characteristics and average performance for each of antiglaucoma medicines by the indicators of efficacy, side effects, actual probability of medicine prescription to date, the prospects of medicine administration, the availability of medicine in pharmacies. Based on the above data we have subdivided antiglaucoma medicines in groups of high, medium and low expediency of inclusion in the formulary and insurance lists.

Key words: primary open-angle glaucoma, antiglaucoma medicines, expert evaluation, formulary and insurance lists.

Отримано 09.08.2016

ISSN 2312-0967. Фармацевтичний часопис. 2016. № 3 